\title{
OTTO EICHELMAN'S VISION OF GEOPOLITICAL PRIORITIES OF THE UPR: EUROPE VERSUS RUSSIA
}

\section{ВІЗІЯ ОТТО ЕЙХЕЛЬМАНА ЩОДО ГЕОПОЛІТИЧНИХ ПРІОРИТЕТІВ УНР: СВРОПА VERSUS РОСІЯ}

\author{
Turchyn Ya.B., \\ Doctor in Political Sciences, \\ Professor at the Department of Political Sciences and International Relations \\ Lviv Polytechnic National University
}

\author{
Ivasechko O.Ya., \\ PhD in Political Sciences, \\ Associate Professor at the Department of Political Sciences and International Relations \\ Lviv Polytechnic National University
}

\author{
Tsebenko O.O., \\ PhD in Political Sciences, \\ Associate Professor at the Department of Political Sciences and International Relations \\ Lviv Polytechnic National University
}

\begin{abstract}
The article deals with O. Eichelman's vision of the geopolitical priorities of the Ukrainian People's Republic (UPR) regarding the process of state self-determination of the Ukrainian people. It was found that Ukraine's place in the geopolitical space $\mathrm{O}$. Eichelman defined through an analysis of the current international situation, including UkrainianRussian and Ukrainian-European relations. Based on his works, economic, political, and historical grounds that prove the European orientation of external development of the Ukrainian state are singled out. One of the important directions of the UNR foreign policy $\mathrm{O}$. Eichelman considered the development of bilateral Russian-Ukrainian relations. It is important that $\mathrm{O}$. Eichelman substantiated the possibility of simultaneous formation of parallel unions between the states of the former Russian empire on international and legal grounds. He emphasized that the free alliance structure between sovereign states neither de facto, nor de jure should prevent the formation of new political ties that are concluded on the basis of joint state interests, and historical grounds, in case of their free membership. As an alternative, $\mathrm{O}$. Eichelman offered an Eastern European Organization, into which the countries located in the territory of the former Russian Empire could enter, but without the territories of the Caucasus and Asia. This gives grounds for concluding that the scholar was a supporter of the multi-vector foreign policy of the UPR as the basis for the implementation of Ukrainian national interest. The emphasis is that among the basic principles of the model of interstate relations $\mathrm{O}$. Eichelman offered not only such inalienable components, such as peace, partnership, equality, but also economic expediency as a guarantee for the realization of national interest. It is concluded that the scientific heritage of $\mathrm{O}$. Eichelman is relevant today both from an academic and socio-political view. The scholar's position regarding the ways of building up Ukrainian statehood is important not only for the development of domestic science on politics but also for state-creating practices in Ukraine today. His scientific developments acquire special importance in the process of today's constitutional reform, improvement of local self-government system, development of priority areas of regional policy, intensification of participation of people's masses in the political sphere, clarification of electoral legislation, creation and implementation of a national development program in its domestic and external dimensions.
\end{abstract}

Key words: Otto Eichelman, Ukraine, state, geopolitical space, UPR.

У статті розглянуто візію О. Ейхельмана щодо геополітичних пріоритетів УНР у процесі державного самовизначення українського народу. З'ясовано, що місце України в геополітичному просторі О. Ейхельман визначив через аналіз тогочасної міжнародної ситуації, у т. ч. україно-російських та україно-європейських відносин. На основі його праць виокремлено економічні, політичні та історичні підстави, що доводять європейську спрямованість зовнішнього розвитку Української держави. Одним із важливих напрямів зовнішньої політики УНР О. Ейхельман вважав розвиток двосторонніх російсько-українських взаємин. Важливим є той фракт, що О. Ейхельман обґрунтував можливість одночасного утворення паралельних союзів між державами колишньої Російської імперії на міжнародноправових підставах. Він наголосив, що вільний союзний устрій між суверенними державами ані de facto, aнi de јure не повинен перешкоджати становленню нових політичних зв'язків, які укладаються на основі спільних державних інтересів, історичних підстав, за умови вільного їх членства. Як альтернативу О. Ейхельман запропонував східноєвропейську організацію, до складу якої могли б увійти країни, розташовані на території колишньої Російської імперії, але без територій Кавказу й Азії. Це дає підстави для висновку, що вчений був прихильником багатовекторності у зовнішній політиці УНР як основи для реалізації українського національного інтересу. Акцентовано увагу на тому, що з-поміж базових принципів моделі міждержавних відносин О. Ейхельман запропонував не лише такі невід'ємні складові частини, як-от: мир, партнерство, рівність, але й економічну доцільність як запоруку для реалізації національного інтересу.

Зроблено висновок про те, що наукова спадщина О. Ейхельмана є актуальною сьогодні як з академічного, так і суспільно-політичного погляду. Позиція вченого щодо шляхів розбудови української державності важлива не тільки для розвитку вітчизняної науки про політику, але й для державотворчої практики в Україні нині. Його наукові 
розробки набувають особливого значення у процесі сьогоденного конституційного реформування, вдосконалення системи місцевого самоврядування, вироблення пріоритетних напрямів регіональної політики, активізації участі народних мас у політичній сфрері, уточнення виборчого законодавства, створенні й імплементації програми національного розвитку в її внутрішньому та зовнішньому вимірах.

Ключові слова: Отто Ейхельман, Україна, держава, геополітичний простір, УНР.

Problem statement. ModernUkrainian researchers are trying to respond to different issues of the political history of our nation, to locate the place of Ukraine in the geopolitical space between East and West, to refute the thesis of "non-historical position" of the Ukrainian nation, which can not have its own state. According to many scholars, the emergence of a country in central Europe that is on par with the leading countries of the continent in terms of size and population is a significant event that has radically changed the political configuration of the Old World [2, p. 3]. As a newly created state, Ukraine immediately showed the desire to find its geopolitical identity, to realize itself in a global civilization context, to decide on its own priorities, and develop its strategy and tactics of their implementation [2, p. 3].

At the same time, Z. Brzesinsky notes that in the international community there is no sufficient understanding of Ukraine's international importance, which in a new way determines the borders of Europe and transforms Russia to the national state. These are extremely crucial changes $[1$, p. 70$]$. From the point of view of classical geopolitics, prove domestic scholars, Ukrainian geostrategy faced the choice of two main paradigms: Eurasian and Euro-Atlantic, which is due to the specifics of the geographical location of Ukraine, its territorial belonging to Europe and Eurasia [13, V. 6, p. 632].

Historical experience shows that the communication oftheUkrainian peoplewithotherstates wasmoreintense in periods of complete or incomplete statehood, and vice versa - in times of lack of state, it was on the periphery of international contacts [13, p. 629]. Confirmation of this was the period of struggle of the Ukrainian people for state self-determination in the international arena during 1917-1921. The position of M. Dnistryansky, a modern researcher of the problems of the political geography substantiates that, despite the extremely unfavorable geopolitical position, the Ukrainian ethnopolitical movement during the XIX-XX centuries in the context of Central Eastern European processes was a real integral geopolitical factor [4, p. 91]. In those socio-political conditions, the UPR leaders found themselves before the problem of finding allies who could offer Ukrainian people military and political assistance to struggle against Bilshovyk aggression. No less important became the international recognition of its state independence. It is reasonable to consider the position of D. Yanevsky that it is impossible to overlook such a fundamentally important circumstance as the complete irrationality of the foreign policy of the newborn Ukrainian state when Ukrainian socialist leaders did not want to understand the circumstance that any political regime, if it wants to remain in power, must and necessarily will act from the position not of abstract ideologues, but rigid geopolitical realities $[15$, p. 155].

Given this, many works Ukrainian scholars have devoted not only to the analysis of the Ukrainian revolution of the beginning of the XXth century and substantiation of possible forms of state development of Ukraine, but also to the definition of its place in the system of international relations, and characteristics of the diplomatic policy of the UPR. It can be argued that the public-political and scientific thought of that time was marked by originality and novel approaches, foremost, in understanding and analysis of geoethnopolitical problems [4, p. 91]. In particular, O. Eichelman, being in emigration and possessing thorough theoretical knowledge and practical experience in the field of legal regulation of the international system, studied intergovernmental relations and the place of Ukraine in them.

Task statement. To achieve the goal of this scientific study, it is necessary to solve several tasks, namely: to locate the position of O. Eichelman concerning Ukrainian-European relations and prove his commitment to the European orientation of external development of the UNR; to highlight his vision of Ukrainian-Russian relations; to justify the approach of O. Eichelman on the multivector inclination of the foreign policy of the UNR; to determine the basic principles of the model of interstate relations according to $\mathrm{O}$. Eichelman; to demonstrate the relevance and importance of the scientific heritage of the researcher in the process of state-building practice in Ukraine today.

Analysis of recent research and publications. The relevance of the chosen topic is intensified by the fact that in the conditions of the Soviet regime, the scientific achievements of the scholar were inaccessible to study. Only with the proclamation of Ukraine's independence, there were new opportunities for the study of socio-political ideas of O.Eichelman. Minimal biographical information about $\mathrm{O}$. Eichelman is found in different reference literature of the authorship of T. Andrusyak, O. Vishka, I. Begej, N. Brailan, T. Ostasko. Important to disclose the socio-political position of the scholar in the context of the development of Ukrainian political science are works of M.Getmanchuk, O. Boryslavska, B. Bronco, M. Buchyn, I. Kopelev, Y. Maneluk, Y. Moroz, O. Moshak, S. Cashchenko, M. Petriv, V. Potlivnitsky, P. Stetsuk, D. Yanevsky, etc. Somewhat wider constitutional ideas of O. Eichelman considered representatives of legal science, in particular 
N. Yefremova, O. Myronenko, A. Prysyazhnyuk, O. Skakun, M. Tomenko. Scientific developments of O. Eichelman were also interesting for specialists in the field of science of international law and diplomacy. In the first place, the works of D. Budkov, D. Vedeneyeva, V. Denysova, L. Zablotska, O. Zadorozhny, V. Korotky and K. Savchuk should be highlighted.

Allocation of unresolved parts of the general problem. The purpose of the proposed publication is to gain clear systemic ideas about the comprehensive study of the geopolitical priorities of the UNR in the process of state self-determination of the Ukrainian people, according to Otto Eichelman.

Presentation of the main research material. O. Eichelman (1854-1943) made a significant contribution to the formation and development of Ukrainian political thought and the improvement of state-building practice. He was a prominent scholar, teacher, legislator, constitutionalist, publicpolitical activist and ideologist of the national liberation movement in Ukraine at the beginning of the XX century. He was not only a famous scholar but also a powerful state figure. Thus, the combination of theorist and practitioner in his person provides the study of his work undeniable importance.

The theoretical scientific research of O. Eichelman started from the period, which was marked by the end of the First World War. At this time, many nations were hoping for a new international order as well as for acquisition of the right to self-determination by non-state nations. It was about the establishment of a "future wellbeing" system, structural elements of which, according to O. Eichelman, were the realization of people's national will, the establishment of peace between states, and decreasing the financial burden of countries due to the reduction of military expenditures, etc. In 1918, the President of the United States, Woodrow Wilson, proclaimed the elements of the general "well-being of mankind" and subsequently noted that the warring parties used them for the conclusion of general peace and preliminary agreements $[10$, p. 113]. The scholar called the holding of the Versailles World Congress of 1919 with the participation of Wilson an important step towards the establishment of a new world order. The Congress, in his opinion, had to launch a new system of international relations, which would guarantee peaceful coexistence between states and nations, creat a new international organization, which would aim to meet the national needs and economic interests of all Member States. Wilson's 14 points on territorial issues, including Russia, Poland, the peoples of AustroHungary, and others, were of strategic importance to Ukraine. During his presentation to Congress, the US President said: "What is recognized as fair to Poles must be recognized by Finns, Lithuanians, Latvians and, presumably, Ukrainians. Since the formation of this principle, new nations have emerged and there is no doubt that they should be given the same opportunities.
This means neither more nor less, but only the recognition by the peace conference of a number of de facto existing governments representing Finns, Latvians, Lithuanians and Ukrainians..." [6, p. 95-96].

However, Wlison's diplomatic experience, according to O. Eichelman, was insufficient to implement this program. As a result, French diplomats took over this initiative. The Treaty of Versailles, on the one hand, consolidated in Western Europe the nature of the coast base for marine states, and on the other hand - created a number of so-called limital states (Finland, Estonia, Latvia, Lithuania, Poland, Czechoslovakia, Romania). Their main geopolitical task was to prevent the creation of a continental alliance of land nations and states; that is, Slavs and Germans, directed against Great Britain and its allies [15, p. 313].

For then-revolutionary Ukraine, the Treaty of Versailles turned into undesirable actions on the part of the Entente. As a result, Poland was in fact allowed to occupy Eastern Galicia and Volhynia, Transcarpathia was ceded to Czechoslovakia, and Bukovyna to Romania. Thus, the Ukrainian side was not given the opportunity to establish control over their lands. The Treaty of Versailles legally established the end of the First World War and finally fixed the post-war distribution of forces in Europe. "The existence of an independent, self-sufficient, and even more so conciliar Ukraine, - indicates D. Yanevsky, this scheme, in any case, did not foresee and could not foresee" $[15$, p. 380$]$. The American side did not fully support the terms of the Treaty of Versailles. Thus, O. Eichelman pointed out one important detail: that the United States did not ratify this agreement, including the article on the establishment of the League of Nations [10, p. 113]. Disappointed with the results of the Congress, W. Wilson still signed the Treaty of Versailles between the Entente countries and Germany on June 28, 1919.

O. Eichelman tried to explain the position of the Americans, who showed their outright dissatisfaction with the Treaty of Versailles. "The Americans", he stated, "as real politicians, obviously accurately calculated the inherent weight of this agreement, clearly predicted the confusion it and subsequent agreements were to cause in relations between nations; they also foresaw real - not to say selfish - interests, which the victors sought to implement at all costs behind the scenes of their outspoken slogans about the freedom of peoples and the high tasks and ideals of mankind, and therefore without any national prejudices and still behave politely, but have an unequivocally cool attitude to the Treaty of Versailles and its extensions" [10, p. 113-114]. From O. Eichelman's point of view, the Treaty of Versailles only intensified the confrontation between France and Germany, and the system of international relations itself acquired 
signs of instability, in the conditions of which became almost impossible to predict the events of international life. The situation was further complicated by the fact that each state had several unresolved complex problems that generated antagonisms. Defending national interest, it was ready to "bargain" for personal benefit. Analyzing the peculiarities of interstate relations, the scholar emphasized that for the implementation of national priorities, the states began to use any means, from diplomatic to economic, namely calculations for state debts, the establishment of currency prices, manipulation of international exchange in conditions of complete destruction of the national economy. Under such conditions, it has become obvious that a number of countries around the world suffer significantly from the "economic stagnation" of European countries. The United States and England, to the conviction of O. Eichelman, recognized the need to rebuild the national-economic well-being of Germany, because they approached the solution of post-war economic problems in Europe prudently and without chauvinism. Instead, the position of France, which dreamed of political revenge in 1870-1871, was different, ignoring the fact that "the question of Alsace-Lorraine turned Europe into an armed camp, and the so-called image of France (for 1870) many times threatened a new war between France and Germany" [10, p. 114]. Given this, there was constant threat of a new war in Europe, which, according to O. Eichelman, could not be localized, and could cause a new "world fire". Such a geopolitical balance of power forced both France and Germany to seek allies. One of the important factors that decisively influenced international relations, O. Eichelman quite rightly called economic [10, p. 114].

He believed that England and the United States at that time had chosen a predominantly neutral, somewhat detached position, adhering to the principles of the Monroe Doctrine (since 1823), and therefore did not interfere in European affairs at all. Attention is focused on the fact that the US economic interests in Europe were implemented, and the wars that periodically arose in its territory, only brought superprofits to American capitalists, increasing their influence on the world political process. It should be noted that the position of O. Eichelman was quite reasonable, because the United States as a result of the First and Second World Wars significantly improved its financial and economic situation. It was sufficiently obvious that when the United States experienced a threat to their economic interests, it was trying to make full use of diplomatic forces. Eichelman cited the 1905 war between Russia and Japan as an example, during which President Roosevelt used all diplomatic means to persuade Russia to make a truce with the Japanese side and not to use military force against it. The defeat of Japan would mean losing Americans the financial loans they were actively lending to it in large amounts. Thus, O. Eichelman argued that in such circumstances, the US attitude to Russia has always been favorable, starting from the end of the XVIII century [10, p. 115].

It was the United States that the scholar rightly called the most powerful factor in the development of the then system of international relations. The US foreign policy has taken a well-defined direction, which O. Eichelman characterized as an "expected attitude" to events in Europe. The US government was well aware that hasty decisions should not be taken in such an uncertain situation. The researcher was convinced that on this basis they were somewhat cool about the activities of the League of Nations, anticipating the possibility of forming a new international organization. Numerous publications in the press of that time served as confirmation.

On the other hand, pursuing its national interest, the United States repeatedly declared its readiness to help Europe in financial support issues. American banks were to be involved in this process, matching their financial policies with the US government. On this basis, it was concluded that "the policy of the States in this way receives in its hands the strongest means in modern circumstances to influence its authority on the diplomacy of economically devastated Europe in all necessary US cases. Full contact with the policy of the States is therefore of paramount interest for the policy of all European states" [10, p. 115].

The scholar rightly pointed out that the realization of US interests would be possible exclusively in a stable political situation in Europe. Trying to realize such a task, American diplomats attempted to influence the position of such countries as England, France, and Germany. The latter, noted O. Eichelman, agreed with the proposed "rules of the game" and declared its readiness to carry out recommendations and guidance of the US Government. Given this fact, the definite merits of American diplomacy include a change in coordinates in relations between France and Germany. Thus, the scholar continued, a seemingly previously impossible meeting of German and French ministers took place as if unexpectedly in Wiesbaden [10, p. 116].

Having carefully analyzed international life, O. Eichelman outlined the probable location of political forces in the system of interstate relations. Thus, France understood the real state of interstate relations and perceived even those circumstances that did not quite suit it. Germany, hoping for more favorable conditions in the future, initially agreed to comply with the provisions of the Treaty of Versailles, despite the "impossibility of its obligations". At the same time, the awareness was mellowing that the Entente bloc was not a permanent phenomenon.

This approach created a basis for understanding that the above-mentioned changes in the system of interstate relations did not contribute to the understanding of the "Ukrainian question", 
which was not given a clearly defined conjuncture in world politics. Most Western European countries did not realize the full importance of the Ukrainian issue, and only passively observed the course of political processes in Ukraine. Thus, the attitude to Ukraine of the German and Austro-Hungarian empires was well-known. From the beginning of the XX century, Germans perceived Ukraine as a factor in weakening Russia, and the possibility of the existence of an independent Ukrainian state was considered exclusively within the framework of the strategy of German expansion to the East $[15$, p. 157]. At the same time, according to modern researchers, the United States in 1917-1920 did not produce a separate political course regarding Ukraine and placed it in the so-called indifference zone. On the other hand, none of the Ukrainian political regimes of the outlined period sought to have a clear policy on the United States. Consequently, Americans arbitrarily interpreted political processes that took place on the territory of the former Russian Empire [15, p. 156]. In fact, the countries of Europe did not take a common position on the problem of selfdetermination of Ukraine, but rather the opposite developed European countries did not share the state aspirations of Ukrainians.

An important feature for O. Eichelman was the fact that when the political side of the issue had not yet reached its solution, the economic importance of Ukraine for the world market was realized and was quite obvious. On the other hand, it seemed that Western political forces "were afraid" to provide active support to the "Ukrainian question". Although already at that time, some of them advised their governments to support the Ukrainian side, considering it an important factor in the process of stabilizing the political and economic life of Europe. "In order to increase this interest in the Ukrainian case, it is necessary", said O. Eichelman, "that it (Ukraine) should also behave in a solid and reasonable way at home, guaranteeing its duration and sustainability" [10, p. 117]. These words of the scholar are relevant even today, when Ukraine is trying to strengthen its influence on the processes of international life.

We can allocate several measures produced by O. Eichelman to strengthen Ukraine's position in international relations: firstly, to intensify the activities of the UPR government, which through the thoughtful and rational use of favorable international political conjuncture can prove to the world its political maturity, balance and experience, devotion to the state course; secondly, in developing a foreign policy course, it is necessary to take into account the lessons of the past, without which the Ukrainian case cannot develop in the desired direction; thirdly, to create a joint strategy of national development, and representatives of the Ukrainian political elite must clearly understand that Ukraine's independence will not be strengthened in certain party programs, and this is not an effective means of fighting the occupants; fourthly, it is necessary to identify a single political unifying goal, namely the full state independence of Ukraine [10, p. 117]. Only in the conditions of an independent and strong state various party programs can be implemented. Such views of the scholar correspond to those he declared in the Statute of the National Union of Ukrainian Statehood. In essence, he proposed to create a unified national strategy for the development of Ukraine's foreign policy following its national interest.

O. Eichelman repeatedly criticized the activities of Ukrainian diplomats, referring to their professional unpreparedness. "Delicate behavior and sweet smiles of foreign diplomats", he stated, "were accepted by them, mostly self-proclaimed "representatives" of the Ukrainian people, as winning of the case" $[9$, p. 10]. At the same time, experienced foreign diplomats successfully used the discord in the Ukrainian political world: "As a result, it came to the point that the state, which was recognized by four countries of the world, to which they sent their diplomatic representatives, was returned to the "dungeon" in which Ukraine was in the days of tsarist Russia" [9, p. 10].

It is obvious, that the diplomatic service played a considerable role in realizing the Ukrainian national interests. Ukrainian diplomat A. Zlenko emphasizes that every thing in politics begins with a person, all political successes and failures have a common main prerequisite - a human factor, regardless of whether it is one person or millions of people: "diplomacy and politics - these are inseparable components of a single whole - determine the fate of the state in the international arena" [11, p. 382].

In 1918-1920, the UPR de facto sent 36 of its representatives abroad (19 embassies, 9 consulates, 8 diplomatic missions), but the activities of Ukrainian diplomats were not effective enough. This was due to insufficient funding for their maintenance, the lack of the very fact of recognition of the UPR by other states. Ukrainian governments did not have clear political guidelines, and large states distrusted the instability of Ukrainian leaders' foreign policy. Besides, the political disunity of the Ukrainian people, their disappointment in the actions of Ukrainian leaders was quite noticeable [3, p. 37-38]. Analyzing the diplomatic activity of the UNR, D. Doroshenko pointed out its peculiarity that "among Ukrainian citizens, there was a kind of "attraction" to go abroad: who only could, tried to enroll in some diplomatic mission and leave. The infinite number of diplomatic missions to all countries of the world were formed. The mass of random elements stuck to the missions and commissions that went abroad" [5, p. 516]. Unsatisfactory diplomatic work weakened Ukraine's position in the international arena, and this was especially felt in the mood of the emigration circles. 
O. Eichelman tried to prove that at each stage of the formation of Ukrainian statehood, determining its place in the system of international relations, the Russian factor played a key role. While in exile, he substantiated the possibility of Ukraine's membership in international unions, taking into account the special nature of UkrainianRussian relations. After the defeat of the national liberation struggle of the Ukrainian people for state independence in 1917-20, this issue was actively discussed in emigration circles, where it was sharply criticized while looking for ways to solve the problem. Thus, Ukrainian emigrants did not lose expectations for Ukraine's political independence. At the same time, a significant contingent of people from Russia was categorical in their assessments of the Ukrainian question and promoted the restoration of the territorial and political system of the Russian Empire [7].

Analyzing the activities of Russian emigration centers, the scholar pointed out to their irreconcilable attitude not only to the foundations of the Soviet regime but also to the fact of the formation of sovereign states that emerged on the territory of the former Russian Empire. "In particular", stated O. Eichelman, "this attitude of Russian circles has become especially hostile in the matter of independence and autonomy of Ukraine" [7]. Indeed, based on preserving the "united and indivisible" Russia, there were no contradictions between the Bolshevik government and the anti-Bolshevik emigration [12, p. 77]. ProRussian political forces considered various ways to restore tsarist Russia, including without states such as Finland and Poland. However, they were united by the desire to restore Russia in the form of a decentralized federal republic. O. Eichelman compared the ideas of decentralization of political power proposed by the Russian emigration with the generally accepted democratic principles of organization of state life to develop proposals for the formation of possible interstate alliances in the future. He allocated the main stages of developing the idea of creating an international union of states that were formerly part of the Russian Empire and outlined the possible prospects for its formation, which actively lobbied the representatives of Russian emigration circles [7].

Going deeper into the political events of the past, O. Eichelman recalled the fact when in January 1918 the Constituent Assembly collected to form a new federal state. However, the Soviet government liquidated them, so they did not achieve their goal. O. Kolchak's, A. Denikin's, and P. Wrangel's attempts to restore "a united and indivisible Russia", he continued, also failed. The Russian political emigration parties set the implementation of a similar task, whose activities intensified in the spring of 1920. According to O. Eichelman, only the Russian Political Committee, which was formed in Warsaw under the leadership of B. Savinkov, carried out its work on fundamentally different principles. Unlike the branches in Paris and Berlin, this committee recognized the right to proclaim their own national states by those nationalities that formed territorially united groups in the territory of former tsarist Russia.

In the context of this issue, O. Eichelman analyzed the results of the meeting held by the Russian Constituent Assembly in January 1921 in Paris, among which we can distinguish: first, it became clear that Russian emigrants in Paris to a certain extent abandoned the previous unequivocal position on the need to preserve a "united and indivisible Russia"; secondly, the meeting still took into account the desire of the peoples to establish a federal-state system in Russia [14, p. 184-185]. Simultaneously, O. Eichelman emphasized the rather "interesting" substantiation of such a position. According to Russian political emigrants, the move towards decentralization of power is the result of tragic circumstances that led to the complete separation of "peripheral states" from Russia, severing with it all ties due to the desire to protect themselves from the despotic power and destructive policies of the Bolshevik dictators. Due to the formation of the Bolshevik regime in Russia, the federal unification of the states of the former tsarist empire into a rational and legal form became impossible. O. Eichelman perceived such a view rather skeptically, mentioning the peculiarities of the so-called democracy in the Russian Empire. The third feature of the meeting of the Constituent Assembly confirmed the scholar's position. Thus, the adopted resolution states that the formation of several nation-states on the territory of the former tsarist empire corresponds to Russia's democratic ideals. Moreover, the legitimacy of the desire of these states to maintain independence is emphasized, if such a position is supported by the Constituent Assembly convened by general elections. The completion of the temporary political separation caused by the Bolshevik regime and the mandatory alliance of Ukraine and Russia in the future after the liquidation of Soviet power can be considered the completion of such "democratic shifts".

The affinity of socio-political and cultural interests determined the common perspective of UkrainianRussian relations, which were interpreted as coercion to economic and political convergence and substantiated by bilateral expediency. The next feature of the meeting, O. Eichelman called the decision on the optimal form of such interstate cooperation - federal unification. The scholar stressed that the resolution, however, does not give a clear definition of the content of such formation. According to him, federal-type unification can be organized based on international law or state law principles. These approaches differ significantly. In the first case, there is a union of states in which its territorial components completely retain sovereignty. As an example, O. Eichelman cited 
the functioning of international organizations in Europe and the United States, including the League of Nations [7]. In the second case, the scholar spoke of a single and indivisible state, when state power unites all its parts, albeit with limited competence. Under such conditions, the centralization of management in the areas of external and military policy is observed.

O. Eichelman's attention was also drawn to the provisions of the adopted resolution on the principles of the accession of sovereign states to the Russian Federal Republic: voluntariness, freedom, and equality of the parties. The scholar, rethinking the lessons of the past, as well as the prospects of Russian-Ukrainian relations, tried to revise the reliability and feasibility of such a proposal.

In general, O. Eichelman didnotrejectthe possibility of a Ukrainian-Russian union and substantiated his position with several arguments. Firstly, the existence in the past of long-term economic ties between Ukraine and the newly formed states of the former Russian Empire. Secondly, the proposed unifying principles corresponded to the democratic preferences of the UPR political leaders, who, according to O. Eichelman, really showed a desire to integrate into such types of forms of interstate unions, as evidenced by the Riga Conference.

As a legislator, O. Eichelman was more interested in the ratio of powers of subjects of such interstate formation. In order to ensure the stability and longterm existence, in the opinion of the researcher, all differences between sovereign states in those or those issues must be regulated by the so-called free agreements. They should be concluded between equal subjects of international law based on wellgrounded needs, and after reaching a mutual agreement of the parties regarding their expediency and content. It was, before all else, about neutralizing differences in the sphere of economic, judicial, and administrative relations, as well as issues of transport and roads, healthcare, etc. Therefore, we can identify clear recommendations of the scholar to ensure the sustainability of such an internationalunion organization. Several factors should determine its stability, namely: the level of realization of the interests of all subjects of international formation, which "encourages them to freely enter this organization and not to violate the legal order established by it"; the term of the international agreement, which O. Eichelman recommended to conclude for 15 years. At the same time, the scholar considered it necessary to leave to the subjects of the union the right to invalidate certain conditions of the contract after its expiration date. In cases when the member states of the international union are not able to resolve controversial issues on their own, they should take advantage of the services of an arbitral court, but under no circumstances resort to armed means. Thus, theoretically, O. Eichelman allowed the formation of joint customs unions, the system of roads and railways, etc., but only between politically independent states. It is more a question of expediency of creation not political, but rather economic unions.

Analyzing the history of the development of interstate relations, O. Eichelman emphasized that the conclusion of this type of international legal unions of sovereign states was a widespread practice. The basis of such alliances was the common vital interests of the parties to the agreement. He also pointed out the peculiarity that they often remained effective longer than a specified term. Interstate associations were not eliminated but supplemented by modified treaties, adapted to the requirements of the socio-political and economic life of the time. The practice of international relations, according to O. Eichelman, contains more than one and a half hundred of these types of regulatory treaties, which "concern those different, typical in modern practice tasks of public administration, which are set by both the united states and the real alliance" [8].

It is important that O. Eichelman substantiated the possibility of simultaneous formation of parallel alliances between the states of the former Russian Empire on international legal grounds. He stressed that a free alliance structure between sovereign states, neither de facto nor de jure, should prevent the formation of new political ties based on common state interests, historical grounds, subject to their free membership. As an alternative, O. Eichelman proposed an Eastern European organization, which could include countries located in the territory of the former Russian Empire, but without the territories of the Caucasus and Asia. An analysis of the source base of the work has shown that the scholar did not name the form of such a political formation, by indicating only its various versions: an agreement based on international legal principles, in the form of a state-legal structure, a real union, or a union state. The possibility was considered to form an ordinary centralized state, which will be part of the newly formed political association - the international legal federal union of the states of former tsarist Russia.

The scholar's attention was drawn to the issue of the proportion between the ideas of state independence, sovereignty, and the formation of interstate alliances. The restoration of state independence of Ukraine was a prerequisite for the creation of international associations, its implementation as a full-fledged subject of world politics. Dominant here was the desire of Ukrainians to live their own national life, and the prerequisites for this - a huge national territory, numerous spiritually and physically healthy population, as well as economic and natural resources of Ukraine. Among the essential features of the Ukrainian process of state construction, O. Eichelman singled out the absence of any claims "to one or another great-power hegemony over anyone. 
It (Ukraine) does not and will never have imperialist inclinations" [8]. This position is because of the fact that in the system of international relations, according to the scholar, Ukrainians preferred a peaceful (arbitration) way of resolving interstate disputes, the development of partnerships with other countries based on norms of contract law, especially with states formed on the territory of the former Russian empire.

As an experienced international lawyer, O. Eichelman came to the conclusion that at the beginning of the XX century "nations have grown to a high degree of national consciousness and are moving towards such new orders which would calm their needs and exclude for the future any frivolity and adventures in international relations" [8]. Thus, the formation of states and large interstate formations was to become a solid foundation for the development of modern world culture in all its directions. Consequently, the formation of international unions the scholar interpreted as a factor in stabilizing the system of international relations, the implementation of the principle of balance of power.

Thus, O. Eichelman, being a positivist by convictions, tried to solve the "Ukrainian question" and determine the place of Ukraine on the geopolitical map of postwar Europe with the help of international law, realizing the influence of the Russian factor on this process. Although he pointed to Ukraine's European orientation, unlike many politicians of the time, he did not reject the possibility of forming a new international union between Ukraine and the former states of the Russian Empire on legal and democratic principles. However, the formation of such an international union in the near future, O. Eichelman considered impossible, because Soviet Russia, according to him, did not comply with any of the declared unifying principles. It turned out that he complied with the position that the historical factor could not be the main factor in building future Ukrainian-Russian or Ukrainian-European relations, but, in any case, peoples should look to the past to prevent mistakes in the future. It is obvious that the scholar was a supporter of Ukraine's multivector orientation in foreign policy, which aims to implement the components of national interest.

O. Eichelman precisely identified the peculiarities of interstate relations after the First World War, as well as their possible evolution. He did not deny Ukraine's entry into interstate alliances but emphasized the democratic principles of their formation and functioning, namely: peace, partnership, mutual respect, as well as economic benefits, equality of the parties, and preservation of state sovereignty of such formations.

Conclusions. It is concluded that the state independence of Ukraine was a necessary condition for the creation of any federal or confederate formations, and their foundation should become the norms of international law, which are designed to guarantee the sovereignty of the state in the system of interstate relations. O. Eichelman sought alternative and multifaceted ways to develop Ukraine's foreign policy in order to fully realize its national interest. The views of the scholar correspond to modern democratic ideals, principles, and norms of international law, and therefore they can be used in both the theory and practice of international life, in the process of ensuring equitable integration of Ukraine into the world community.

\section{REFERENCES:}

1. Бжезінський 3. Велика шахівниця. Львів ; Івано-Франківськ : Лілея-НВ, 2000. 236 с.

2. Гетьманчук М.П. Між Москвою та Варшавою : українське питання у радянсько-польських відносинах міжвоєнного періоду (1918-1939рр.). Львів : Вид-во Національного університету «Львівська політехніка», 2008. 432 c.

3. Гетьманчук М.П. Ризький мир: україно-польські відносини періоду підготовки, підписання і ратифікації Ризького договору 1921 р. Львів : Світ, 1998. 53 с.

4. Дністрянський М.С. Етнополітична географія України: проблеми теорії, методології, практики : монографія. Львів : Літопис : Видавничий центр ЛНУ імені Івана Франка, 2006. 490 с.

5. Дорошенко Д. Мої спомини про недавнє минуле (1914-1920) : науково-популярне видання. Київ : Темпора, 2007. 632 с.

6. Дорошенко-Товмацький Б. Симон Петлюра: життя і діяльність. Київ : Вид. центр «Просвіта», 2005. $608 \mathrm{c}$.

7. Ейхельман О. Про єднання держав, які повстали б. російської імперії з новою Росією. Українська трибуна. 1922. 31 (18) січня.

8. Ейхельман О. Про єднання держав, які повстали б. російської імперії з новою Росією. Українська трибуна. 1922. 1 лютого (19) січня.

9. Ейхельман О. С.У.Д. Київ : Тарнів : Вид-во С.У.Д., 1921. 79 с.

10. Ейхельман О. Стан сучасної дипломатії. Визволення. Прага, 1921. Ч. 5/8. С.113-118.

11. Зленко П. Бібліографічний покажчик наукових праць української еміграції 1920-1931. Прага, 1932. 154 c.

12. Мельник І.А. Міжнаціональні відносини : радянський експеримент та історичні реалії. Київ : Либідь, 2006. 468 c.

13. Політична історія України. XX ст. : у 6 т. Т. 1 : На зламі століть (кінець XIX ст. - 1917 р.) / Ю.А. Левенець, Л.П. Нагорна, М.С. Кармазіна ; за ред. І.Ф. Курас. Київ : Генеза, 2002. 424 с.

14. Яневський Д. Політичні системи України 1917-1920 років: спроби творення і причини поразки. Київ : Дух і література, 2003. 767 с. 